Doi: https://doi.org/10.24036/jep/vol5-iss2/612

\title{
Local Instructional Theory Topik Dua Tipe Kesalahan dalam Pengujian Hipotesis
}

\author{
Syafriandi ${ }^{1}{ }^{*}$, Ahmad Fauzan ${ }^{2}$, Lufri $^{3)}$, Armiati $^{2)}$ \\ 1) Jurusan Statistika, FMIPA, Universitas Negeri Padang \\ 2)Jurusan Matematika, FMIPA, Universitas Negeri Padang \\ ${ }^{3)}$ Jurusan Biologi, FMIPA, Universitas Negeri Padang \\ *) syafriandi_math@fmipa.unp.ac.id
}

\begin{abstract}
Two types of errors are one of the important topics in hypothesis testing. Studying the two types of errors is not only studying how the procedure determines the probability of making an error, but it is very important to study the theoretical concepts of the two types of errors. To achieve this goal, a learning design is needed that can facilitate students to construct their own concepts of the two types of errors. The learning design developed is local instructional theory resulting from the cyclic process of hypothetical learning trajectory. The type of research used is design research using the model developed by Gravemeijer and Cobb. The test subjects used in this study were students of the Ma thematics Education Study Program, FMIPA UNP who took the Elementary Statistics Course in the July December 2019 semester. This research resulted in a very practical local instructional theory used to facilitate students in carrying out horizontal and vertical mathematization processes, so that students are able to construct their own concepts of two types of errors in hypothesis testing.
\end{abstract}

Keywords : Hypothetical learning trajectory, Local instructional theory, Two types of errors, Hypothesis testing

This is an open access article distributed under the Creative Commons 4.0 Attribution License, which permits unrestricted use, distribution, and reproduction in any medium, provided the original work is properly cited. $@ 2021$ by author.

\section{PENDAHULUAN}

Kerangka Kualifikasi Nasional Indonesia (KKNI) menetapkan bahwa Pendidikan Sarjana paling rendah harus memiliki jenjang kualifikasi Level 6. Menurut Peraturan Presiden RI No. 8 Tahun 2012, kemampuan yang diharapkan pada jenjang kualifikasi Level 6 antara lain adalah (1) menguasai konsep teoretis bidang pengetahuan tertentu secara umum dan konsep teoretis bagian khusus dalam bidang pengetahuan secara menda lam, serta mampu memformulasikan penyelesai an masalah prosedural; (2) mampu mengambil keputusan yang tepat berdasarkan analisis infor masi dan data, dan mampu memberikan petujuk dalam memilih berbagai alternatif solusi secara mandiri dan kelompok. Untuk memenuhi tuntut an jenjang kualifikasi Level 6 tersebut, pembela jaran di perguruan tinggi harus mampu memfa silitasi mahasiswa untuk mampu mencapai jen jang kualifikasi tersebut. Mahasiswa tidak hanya dilatih untuk mampu menerapkan berbagai prose dur, tetapi juga mampu menguasai konsep teoretis dari topik yang dipelajari.

Pengujian hipotesis merupakan salah satu topik penting dalam Statistika Inferensial. Mem pelajari topik pengujian hipotesis bukan hanya mampu memanfaatkan prosedur baku yang telah disediakan dalam berbagai buku referensi (Blu men, 2012; Brase \& Brase, 2012; Triola, 2012), tetapi yang tidak kalah penting adalah memaha mi konsep teoretis dari pengujian hipotesis ter sebut. Hal ini sejalan dengan laporan American Statistics Assosiation's (2016) yang menyatakan bahwa tujuan mempelajari topik pengujian hipo tesis adalah agar mahasiswa lebih fokus pada pe mahaman konseptual dan pencapaian literasi, da ri pada hanya sekedar mempelajari seperangkat alat dan prosedur.

Tujuan utama dalam pengujian hipotesis adalah memutuskan apakah menerima atau me nolak hipotesis nol yang telah dirumuskan. Ke putusan yang diambil dalam pengujian hipotesis memanfaatkan data sampel. Mungkin saja kepu tusan yang sesuai dengan data populasi adalah benar atau bisa jadi tidak benar. Ada empat kemungkinan keputusan dalam pengujian hipo tesis seperti disajikan pada Tabel 1.

Tabel 1. Kemungkinan Keputusan dalam Pengujian Hipotesis

\begin{tabular}{ccc}
\hline $\begin{array}{c}\text { Keputus } \\
\text { an Uji }\end{array}$ & \multicolumn{2}{c}{ Keadaan Sesungguhnya } \\
$\mathbf{H}_{\mathbf{0}}$ Benar & $\mathbf{H}_{\mathbf{0}}$ Salah \\
\hline \multirow{2}{*}{ Terima $\mathbf{H}_{\mathbf{0}}$} & $\begin{array}{c}\text { Keputusan yang } \\
\text { Benar }\end{array}$ & Galat Jenis II \\
& $\mathrm{P}($ Kepercayaan) $=1-\alpha$ & $\mathrm{P}($ Galat Jenis II $)=\beta$
\end{tabular}




$\begin{array}{ccc}\begin{array}{c}\text { Tolak } \\ \mathbf{H}_{\mathbf{0}}\end{array} & \begin{array}{c}\text { Galat Jenis I } \\ \mathrm{P}(\text { Galat Jenis I })=\alpha\end{array} & \begin{array}{c}\text { Keputusan yang } \\ \text { Benar }\end{array} \\ \mathrm{P}(\text { Kuasa Uji })=1-\beta\end{array}$

Tabel 1 memperlihatkan terdapat dua tipe kesalahan dalam pengujian hipotesis, yaitu Kesa lahan Jenis I (Galat Jenis I) dan Kesalahan Jenis II (Galat Jenis II). Galat Jenis I disebut juga se bagai kesalahan positif, yakni menolak hipotesis nol yang benar. Sedangkan Kesalahan Jenis II di sebut kesalahan negatif, yakni menerima hipote sis nol yang salah. Kesalahan Jenis I dan II tidak pernah dapat dihindari, namun dapat diperkecil dengan meningkatkan ukuran sampel. Hal ini sa ngat relevan dengan kejadian sehari-hari, yakni manusia sebagai ciptaan Tuhan, tidak luput dari kesalahan. Kesalahan yang dilakukan manusia juga dapat digolongkan menjadi dua jenis, yakni melanggar perintah (relevan dengan Galat Jenis I), dan melakukan apa yang dilarang (relevan de ngan Galat Jenis II), dan manusia selalu berusa ha untuk memperkecil kesalahan tersebut.

Berbagai hasil penelitian menunjukkan bahwa mempelajari topik pengujian hipotesis ter masuk juga mempelajari kesalahan uji dalam pengujian hipotesis lebih difokuskan pada pro sedur pengujian, sementara konsep-konsep men dasar pada tataran teoretis sering dibaikan. Hasil penelitian Lemsan \& House (2012), dan Jacob (2013) menemukan bahwa pembelajaran topik pengujian hipotesis selama ini masih bersifat konvensional yang lebih mengutamakan prose dur perhitungan dari pada memperkuat pengeta huan konseptual secara bersamaan. Alur belajar yang digunakan selama ini cenderung memberi kan secara langsung konsep dan prosedur peng ujian hipotesis, selanjutnya mahasiswa dilatih un tuk menerapkan ke berbagai masalah menggu nakan prosedur tersebut. Akibatnya mahasiswa mengalami berbagai kesulitan diantaranya $\mathrm{ku}$ rang terampil mengidentifikasi hipotesis nol dan hipotesis alternatif, kesalahan menafsirkan ting kat signifikansi dan p-value, dan gagal untuk me mahami peran distribusi sampling dalam pengu jian hipotesis (Castro,2007; Batanero, 2000).

Sehubungan dengan masalah yang dipa parkan di atas, perlu dirancang desain pembela jaran pada topik pengujian hipotesis. Pada arti kel ini diuraikan hasil desain pembelajaran un tuk materi dua tipe kesalahan dalam pengujian hipotesis yang merupakan salah satu hasil pene litian pengembangan dari Disertasi penulis (Syaf riandi, 2020). Desain pembelajaran yang dikem bangkan berupa Local Instructional Theory (LI
T). LIT merupakan teori spesifik tentang bagai mana membelajarkan suatu topik tertentu yang memuat urutan kegiatan dan tugas untuk mendu kung pengembangan pemahaman mahasiswa ten tang tujuan pembelajaran yang spesifik. Simon (1995); Daro, dkk. (2011); Gravemeijer \& Cobb (2013); Bahamonde, dkk. (2016); dan Larson, dkk (2017) mengungkapkan bahwa LIT sangat membantu menjembatani peneliti dan praktisi untuk mengevaluasi dan memikirkan ulang pem belajaran yang telah dilakukan.

Untuk menghasilkan LIT terlebih dahulu dirancang hypothetical learning trajectory (HL T) yang keterlaksanaannya perlu dibuktikan sela ma kegiatan pembelajaran dan direvisi melalui proses siklik (Fauzan, dkk., 2020; Syafriandi, dkk. 2020). Selanjutnya, Simon (1995); Grave meijer (2014); dan Larson, dkk (2017) mengung kapkan bahwa terdapat tiga komponen penting dalam HLT, yaitu (1) tujuan pembelajaran (le arning goal) yang mendefinisikan arah yang akan dicapai dalam pembelajaran; (2) aktivitas pembelajaran (learning activites) berupa ran cangan alur belajar yang akan dilalui mahasiswa untuk mecapai tujuan pembelajaran; dan (3) hi potesis proses pembelajaran (hypothetical learn ing process), berupa prediksi dan antisipasi ba gaimana pikiran dan pemahaman mahasiswa akan berkembang dalam kegiatan pembelajaran.

Sztajn, Confrey, Wilson, dan Edgington (2012) menjelaskan bahwa HLT berfungsi seba gai peta jalan bagi pendidik dalam mengidentifi kasi tujuan pembelajaran, menafsirkan pemikir an matematis peserta didik, dan ketepatan meres pon dengan menggunakan instruksi yang tepat. Hypothetical learning trajectory dimulai dari apa yang telah diketahui peserta didik terkait de ngan konsep yang akan dipelajari, selanjutnya mengidentifikasi kendala-kendala yang mungkin dialami peserta didik untuk mempelajari konsep yang lebih formal, serta menyiapkan antisipasi untuk memfasilitasi peserta didik mengatasi ken dala-kendala tersebut (Confrey, Gianopulos, Mc Gowan, Shah, \& Belcher, 2017). Sejalan dengan hal itu, Gravemeijer (2004) merekomendasikan penggunaan pendekatan Realistic Mathematics Education (RME) untuk mendesain HLT.

Menurut Gravemeijer \& Cobb (2013) pen dekatan RME menitikberatkan bahwa matemati ka dipahami sebagai aktivitas manusia, dan pem belajaran matematika menurut RME adalah me lakukan (doing) matematika. Mahasiswa difasili tasi untuk menemukan strategi sendiri dalam me nyelesaikan suatu masalah dengan memanfaat 
kan fenomena kontektual (matematisasi horizon tal) yang digunakan untuk menuju matematika formal (matematisasi vertikal). Lebih lanjut, Van den Heuvel \& Drijver (2020) menguraikan enam prinsp pembelajaran berbasis RME, yaitu: (1) Prinsip aktivitas (Activity principle), maha siswa diperlakukan sebagai peserta aktif dalam proses pembelajaran; (2) prinsip realitas (reality principle), belajar matematika harus dimulai dari masalah kontekstual yang nyata dalam pi kiran mahasiswa; (3) prinsip level (level prin ciple), belajar matematika berarti melewati bebe rapa tingkat/level; (4) prinsip keterkaitan (inter twinement principle), mengintegrasikan berba gai topik matematika dalam satu kegiatan pem belajaran; (5) prinsip interaktivitas (interactivity principle), pembelajaran matematika tidak ha nya merupakan aktivitas individu tetapi juga akti vitas sosial; dan (6) prinsip bimbingan (guidan ce principle), penemuan kembali secara terbim bing.

Pada artikel ini dipaparkan proses desain HLT berbasis RME pada topik dua tipe kesalah an dalam pengujian hipotesis, sehingga mengha silkan Local Instructional Theory yang praktis (dapat digunakan, mudah digunakan, dan memili ki daya tarik).

\section{METODE PENELITIAN}

Jenis penelitian yang digunakan dalam pe nelitian ini adalah penelitian desain (design re search) tipe validation study. Plomp (2013) men definisikan bahwa design research tipe valida tion study merupakan suatu tipe penelitian de sain berupa studi intervensi pendidikan (seperti proses pembelajaran, lingkungan belajar, dan se jenisnya) dengan tujuan untuk mengembangkan atau memvalidasi teori tentang proses pembela jaran dan bagaimana merancangnya. Model pengembangan yang digunakan adalah model yang dikembangkan oleh Gravemeijer dan Cobb (2013), yang terdiri dari tiga fase, yaitu (1) fase persiapan percobaan (preparing for the expe riment); (2) fase uji coba desain di kelas (experi menting in the classroom); dan (3) fase analisis retrospektif (retrospective analysis).

Subjek uji coba dalam penelitian ini ada lah mahasiswa Program Studi Pendidikan Mate matika FMIPA UNP yang mengikuti Mata $\mathrm{Ku}$ liah Statistika Elementer pada Semester Juli Desember 2019. Untuk mengetahui kepraktisan HLT yang dihasilkan, digunakan instrumen ang ket yang disebarkan kepada subjek uji coba.
Untuk menentukan kepraktisan HLT yang dihasilkan digunakan rumus

$$
R=\frac{\sum V_{i j}}{n m}
$$

dengan $\mathrm{R}$ adalah rata-rata hasil praktikalitas yang dihitung menggunakan rumus, $\mathrm{V}_{\mathrm{ij}}$ adalah skor peni laian responden ke-j terhadap kriteria ke-i, $n$ ada lah banyaknya responden yang menilai, dan $m$ adalah banyaknya pilihan kriteria yang dinilai. Kriteria kepraktisan yang diguna kan seperti terli hat pada Tabel 2.

Tabel 2. Kriteria Praktikalitas

\begin{tabular}{cc}
\hline Nilai Validitas & Kriteria Praktikalitas \\
\hline $\mathrm{R}>3,20$ & Sangat Praktis \\
$2,40<\mathrm{R} \leq 3,20$ & Praktis \\
$1,60<\mathrm{R} \leq 2,40$ & Cukup Praktis \\
$0,80<\mathrm{R} \leq 1,60$ & Kurang Praktis \\
$\mathrm{R} \leq 0,80$ & Tidak Praktis \\
\hline & Sumber: Muliyardi (2006)
\end{tabular}

\section{HASIL DAN PEMBAHASAN}

Sesuai dengan fase pengembangan yang digunakan, pada bagian ini dijelaskan hasil fase persiapan percobaan, hasil fase uji coba desain di kelas, dan hasil fase analisis retrospektif. Pada fase persiapan percobaan dirancang HLT ber basis RME dengan terlebih dahulu dirancang ice berg yang menggambarkan proses matematisasi horizontal dan matematisasi vertikal. Iceberg ha sil rancangan dapat dilihat pada Gambar 1.

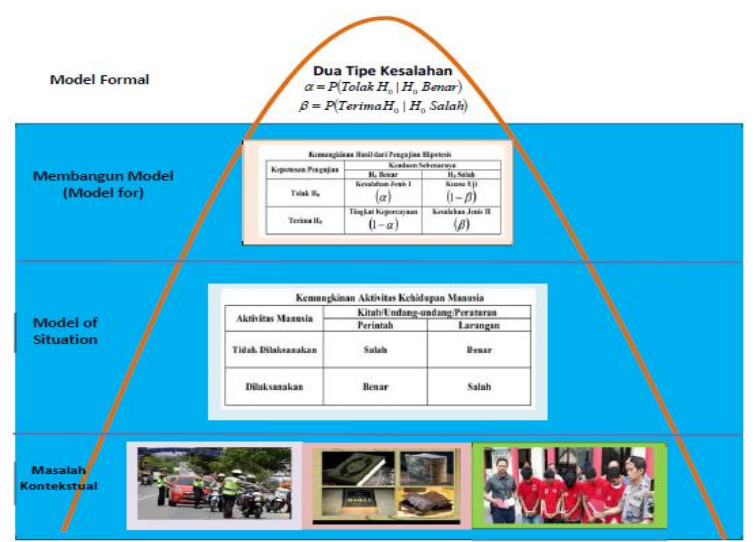

Gambar 1. Iceberg Dua Tipe Kesalahan dalam Pengujian Hipotesis

Terdapat dua tujuan pembelajaran yang ingin dicapai dalam topik ini, yaitu (1) mahasis wa dapat mengonstruksi konsep dua tipe kesa lahan dalam pengujian hipotesis memanfaatkan kegiatan keseharian manusia; dan (2) menentu kan besarnya peluang melakukan Galat Jenis I 
dan II memanfaatkan kasus efektivitas vaksin he patitis $\mathrm{B}$.

Mahasiswa melakukan proses matematisa si horizontal dengan mengemukakan berbagai contoh aktivitas yang pernah dilakukan manusia dalam kehidupannya (masalah kontekstual). Se lanjutnya membangun model of situation meng gunakan tabel atau grafik dengan cara mengkla sifikasikan contoh tersebut menjadi empat kate gori aktivitas manusia, yaitu: (1) menjalankan aktivitas sesuai aturan/norma yang berlaku (me laksanakan apa yang diperintah); (2) melakukan aktivitas pada hal aktivitas tersebut tidak sesuai dengan norma/aturan (melakukan apa yang dila rang); (3) tidak menjalankan aktivitas sesuai atu ran/norma (tidak melaksanakan apa yang diperin tah); dan (4) tidak melakukan aktivitas, jika akti vitas tersebut tidak sesuai dengan aturan/norma yang berlaku (tidak melakukan apa yang dila rang). Memanfaatkan model of mahasiswa mem bangun model for untuk memperoleh konsep Ga lat Jenis I dan Galat Jenis II. Akhirnya, dengan memanfaatkan konsep peluang bersyarat, maha siswa memperoleh model formal tentang besar nya peluang melakukan Galat Jenis I dan Galat Jenis II.

Berdasarkan iceberg yang telah dirancang disusun HLT. Alur belajar yang dirancang beser ta aktivitas dan tujuan yang ingin dicapai pada setiap aktivitas dapat dilihat pada Tabel 3 dan Tabel 4.

Tabel 3. Tujuan dan Aktivitas Pembelajaran pada HLT untuk Aktivitas 1

\begin{tabular}{l} 
Tujuan Pembelajaran (Learning Goal) \\
Mahasiswa mampu mengonstruksi konsep dua tipe kesalahan \\
dalam pengujian hipotesis memanfaatkan berbagai kesalahan \\
yang pernah dilakukan manusia. \\
\hline Aktivitas Pembelajaran (Learning Activities) \\
1. Mahasiswa menelaah masalah kontekstual yang diberikan, \\
dan setiap mahasiswa mengidentifikasi perintah dan larangan \\
yang termuat dalam kitab suci, atau dalam peraturan \\
perundang-undangan yang terkait dengan masalah kontektual. \\
(Tujuan aktivitas: memahami konsep perintah dan larangan \\
yang relevan dengan $\mathrm{H}_{0}$ benar dan $\mathrm{H}_{0}$ salah). \\
2. Mamanfaatkan hasil pada bagian 1, mahasiswa memberikan \\
contoh aktivitas yang pernah dilakukan manusia terkait \\
dengan menjalankan perintah, melanggar perintah, menjauhi \\
larangan, dan tidak mengindahkan larangan (Tujuan \\
aktivitas: memahami konsep terkait dengan mematuhi dan \\
melanggar aturan. Hal ini relevan dengan menerima dan \\
menolak $\mathrm{H}_{0}$ ) \\
3. Menyusun kalimat majemuk berupa pernyataan bersyarat \\
yang mengaitkan hasil yang diperoleh pada bagian 1) dan 2). \\
(Tujuan aktivitas: memahami konsep kejadian bersyarat, \\
yang diperlukan untuk memutuskan hasil pengujian hipotesis) \\
4. Mengklasifikasikan kalimat majemuk yang diperoleh pada \\
bagian 3, dengan memanfaatkan berbagai bentuk represantasi \\
(tabel atau grafik). (Tujuan aktivitas: menemukan ciri-ciri \\
aktivitas yang benar dan aktivitas yang salah)
\end{tabular}

5. Manemukan konsep jenis kesalahan dalam pengujian hipotesis dengan mamanfaatkan hasil yang diperoleh pada bagian 4. (Tujuan aktivitas: menemukan dua tipe kesalahan dalam pengujian hipotesis)

Tabel 4. Prediksi dan Atisipasi pada HLT untuk Aktivitas 1

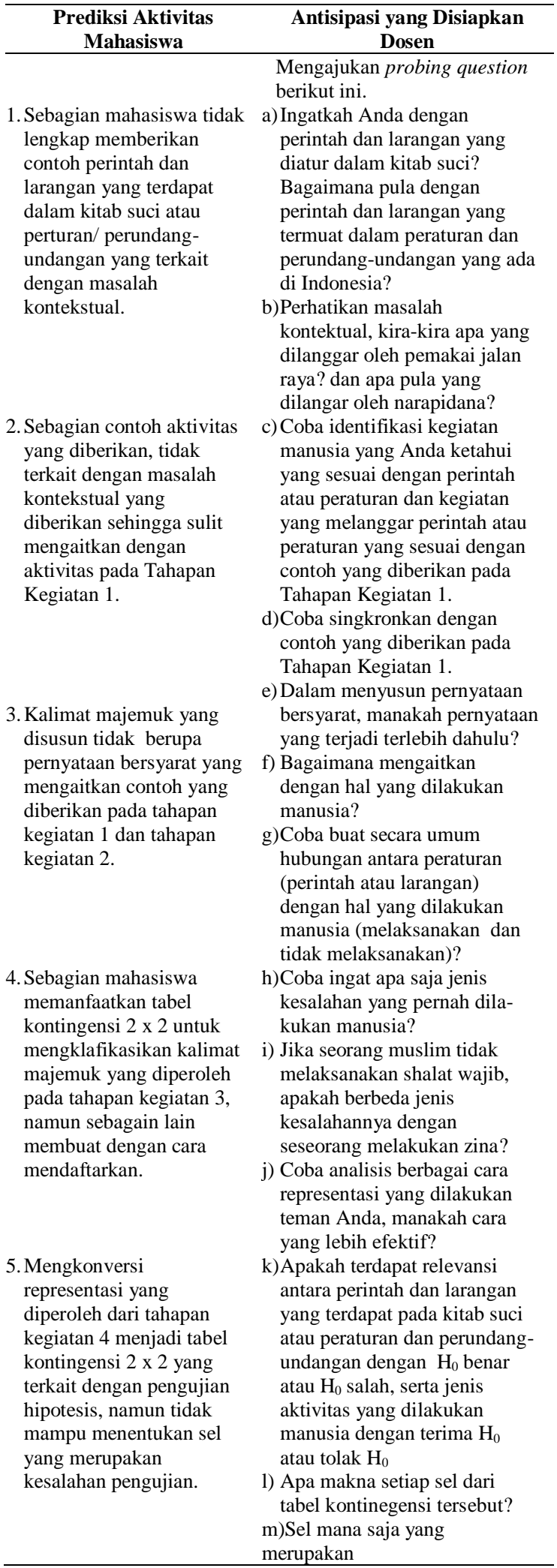




\begin{tabular}{|c|c|}
\hline $\begin{array}{c}\text { Prediksi Aktivitas } \\
\text { Mahasiswa }\end{array}$ & $\begin{array}{c}\text { Antisipasi yang Disiapkan } \\
\text { Dosen }\end{array}$ \\
\hline $\begin{array}{l}\text { 6. Bingung mengkonversi } \\
\text { representasi yang dibuat } \\
\text { sehingga tidak mampu } \\
\text { mendeteksi jenis kesalah - } \\
\text { an dalam pengujian } \\
\text { hipotesis. }\end{array}$ & $\begin{array}{l}\text { suatu kesalahan? } \\
\text { n) Ingat bahwa jenis kesalahan } \\
\text { berupa menolak sesuatu yang } \\
\text { benar, atau menerima sesuatu } \\
\text { yang salah. Dapatkah ini } \\
\text { dimanfaatkan untuk membuat } \\
\text { tabel kontingensi } 2 \text { x 2, terkait } \\
\text { jenis kesalahan dalam } \\
\text { pengujian hipotesis? }\end{array}$ \\
\hline
\end{tabular}

Selanjutnya, Tabel 5 menyajikan tujuan dan aktivitas pembelajaran pada Aktivitas 2.

Tabel 5. Tujuan dan Aktivitas Pembelajaran pada HLT untuk Aktivitas 2

Tujuan Pembelajaran (Learning Goal)

Mahasiswa mampu menentukan besarnya peluang melakukan

Galat Jenis I dan Galat Jenis II memanfaatkan efektifitas

vaksin Hepatitis B.

Aktivitas Pembelajaran (Learning Activities)

1. Mahasiswa menelaah kasus efektivitas vaksin hepatitis B.

Tujuan aktivitas: Mampu mengaitkan masalah kontekstual dengan dua tipe kesalahan.

2. Merumuskan $\mathrm{H}_{0}$ dan $\mathrm{H}_{1}$ dari kasus tersebut.

Tujuan aktivitas: Mampu merumuskan $\mathrm{H}_{0}$ dan $\mathrm{H}_{1}$ dari kasus riil.

3. Mendeteksi distribusi yang sesuai dengan kasus tersebut.

Tujuan aktivitas: Terampil mendeteksi distribusi yang sesuai dengan kasus riil

4. Mamanfaatkan distribusi yang sesuai, mahasiswa

menentukan besarnya peluang melakukan kesalahan jenis I dan II.

Tujuan aktivitas: Mampu menentukan besarnya peluang melakukan kesalahan dalam pengujian hipotesis dari kasus riil.

Prediksi dan antisipasi bagaimana pikiran dan pemahaman mahasiswa akan berkembang dalam melakukan aktivitas 2 disajikan pada Tabel 6.

Tabel 6. Prediksi dan Atisipasi pada HLT untuk Aktivitas 2

\begin{tabular}{|c|c|}
\hline $\begin{array}{l}\text { Prediksi Aktivitas } \\
\text { Mahasiswa }\end{array}$ & $\begin{array}{c}\text { Antisipasi yang Disiapkan } \\
\text { Dosen }\end{array}$ \\
\hline $\begin{array}{l}\text { 1. Mampu menalaah kasus, } \\
\text { namun tidak dapat } \\
\text { mengaitkan dengan materi } \\
\text { pengujian hipotesis. }\end{array}$ & $\begin{array}{l}\text { Mengajukan probing question } \\
\text { berikut ini. } \\
\text { a) Adakah kaitan kasus ini } \\
\text { dengan materi pengujian } \\
\text { hipotesis? } \\
\text { b) Kalimat manakah yang } \\
\text { mengindikasi bahwa kasus } \\
\text { tersebut memuat materi } \\
\text { pengujian hipotesis? } \\
\text { c) Coba telaah konsep-konsep } \\
\text { apa saja yang terkait dengan } \\
\text { kasus tersebut! }\end{array}$ \\
\hline $\begin{array}{l}\text { 2. Bingung menentukan } \\
\text { parameter, sehingga } \mathrm{H}_{0} \\
\text { dan } \mathrm{H}_{1} \text { yang dirumuskan } \\
\text { tidak tepat. }\end{array}$ & $\begin{array}{l}\text { d)Parameter apakah yang terkait } \\
\text { dengan kasus tersebut? } \\
\text { e) Pernyataan yang termuat } \\
\text { dalam kasus tersebut dapat }\end{array}$ \\
\hline $\begin{array}{l}\text { 3. } \mathrm{H}_{1} \text { yang dirumuskan tidak } \\
\text { sesuai dengan kasus } \\
(\text { menggunakan }>\text { atau }<\text { ) }\end{array}$ & $\begin{array}{l}\text { digunakan untuk merumuskan } \\
\mathrm{H}_{0} \text { atau } \mathrm{H}_{1} \text { ? } \\
\text { f) Coba cermati ulang, jika } \mathrm{H}_{0} \\
\text { telah dirumuskan, apakah } \\
\text { rumusan yang sesuai untuk }\end{array}$ \\
\hline $\begin{array}{l}\text { 4. Bingung menentukan } \\
\text { distribusi yang sesuai }\end{array}$ & $\mathrm{H}_{1}$ ? \\
\hline
\end{tabular}

\begin{tabular}{|c|c|}
\hline $\begin{array}{c}\text { Prediksi Aktivitas } \\
\text { Mahasiswa }\end{array}$ & $\begin{array}{l}\text { Antisipasi yang Disiapkan } \\
\text { Dosen }\end{array}$ \\
\hline $\begin{array}{l}\text { dengan kasus. Beberapa } \\
\text { berpendapat bahwa kasus } \\
\text { tersebut mengikuti } \\
\text { distribusi Normal atau } \\
\text { Poisson. } \\
\text { 5. Mampu menetukan } \\
\text { peluang melakukan } \\
\text { kesalahan Jenis I dan II, } \\
\text { namun distribusi yang } \\
\text { digunakan tidak sesuai. }\end{array}$ & $\begin{array}{l}\text { g)Adakah distribusi lain yang } \\
\text { sesuai dengan kasus ini? } \\
\text { h)Coba telaah ulang, ciri-ciri } \\
\text { dari berbagai distribusi! } \\
\text { Distribusi mana yang sesuai } \\
\text { dengan kasus ini? } \\
\text { i) Bagaimana teknik mengitung } \\
\text { peluang yang telah } \\
\text { dirumuskan? }\end{array}$ \\
\hline
\end{tabular}

Untuk uji coba desain (HLT) disusun Buku Pan duan Dosen dan Buku Panduan Mahasiswa. Beri kut ini disajikan hasil fase uji coba desain di ke las dan analisis retrospektif.

Pertama, mahasiswa diminta mencermati masalah kontektual seperti tampak pada Gambar 2. Selanjutnya mahasiswa menelaah perintah dan larangan yang sesuai dengan kasus tersebut, dan mengidentifikasi tingkah laku yang pernah dilakukan manusia, baik yang sesuai perintah, melanggar perintah, menghindari larangan, atau melakukan hal-hal yang dilarang.

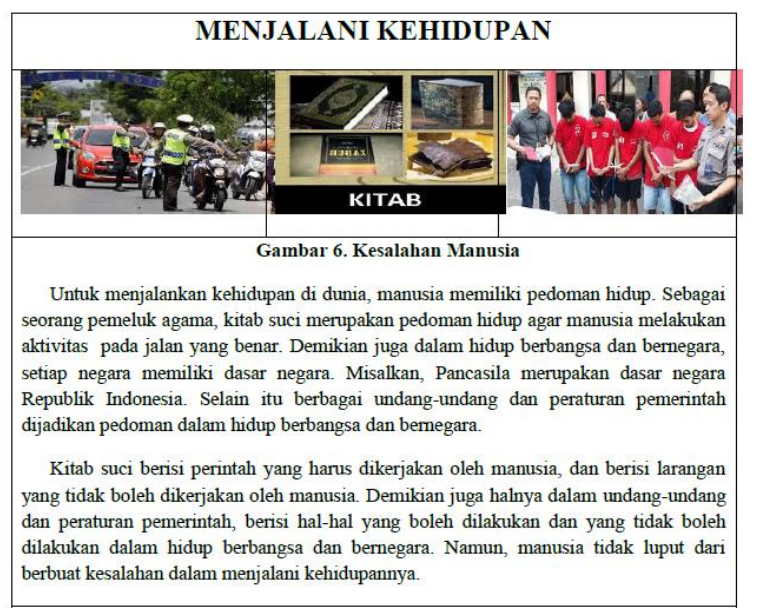

Gambar 2. Masalah Konstekstual Dua Tipe Kesalahan dalam Pengujian Hipotesis

Sebagian besar mahasiswa telah mampu memberikan contoh perintah dan larangan yang termuat dalam kitab suci ataupun dalam pera turan dan perundang-undangan yang berlaku, Mahasiswa juga telah mampu memberikan con toh aktivitas manusia terkait dengan perintah dan larangan sesuai dengan masalah kontekstual yang diberikan. Namun, mahasiswa belum dapat mengaitkan keduanya dalam bentuk kalimat ma jemuk berupa pernyataan bersyarat, sehingga su lit mengidentifikasi dua tipe kesalahanan yang pernah dilakukan manusia dalam kehidupan se hari-hari. Gambar 3 menyajikan hasil kerja salah seorang mahasiswa. 


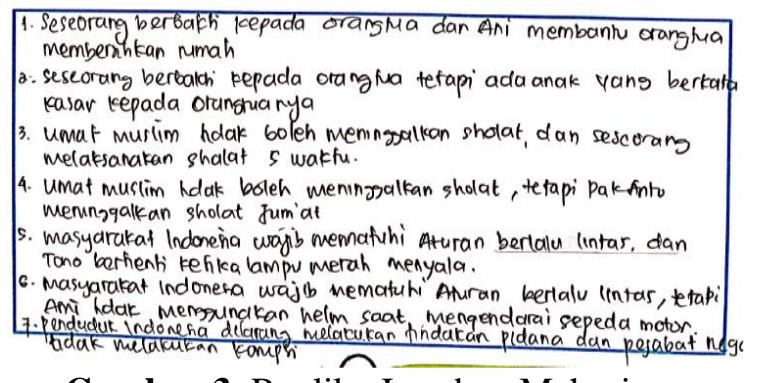

Gambar 3. Replika Jawaban Mahasiswa

Terkait dengan hasil aktivitas yang dilakukan mahasiswa seperti pada Gambar 3, dosen menga jukan probing questions untuk memfasilitasi ma hasiswa menemukan dua tipe kesalahan yang di lakukan manusia dalam kehidupan. Berikut ada lah petikan hasil wawancara antara dosen dan mahasiswa.

Dosen: Apa yang telah dapat Anda identifikasi terkait dengan perintah dan larangan yang terdapat dalam kitab suci?

Mahasiswa: Umat muslim wajib mengerjakan shalat lima waktu, dan dilarang berjudi.

Dosen: Bagus, lalu apa contoh perlakuan manu sia terhadap dua hal tersebut?

Mahasiswa: ada umat muslim yang tidak melaku kan shalat lima watu pak, namun seba gian besar melakukan shalat lima waktu tersebut. Demikian juga banyak umat muslim yang tidak melakukan judi, na mun sebagian kecil ada juga yang mela kukan judi.

Dosen: Nah, kalau demikian dapatkah hal ter sebut dibuat menjadi kalimat majemuk berupa pernyataan bersyarat?

Mahasiswa: Bingung pak.

Dosen: dari dua kelompok pernyataan tersebut, pernyataan mana yang terjadi terlebih dahulu?

Mahasiswa: Aturan pada kitab suci pak.

Dosen: Oke, kalau begitu bagaimana bentuk pe rnyataan majemuknya?

Mahasiswa: Shalat lima waktu adalah wajib, na mun masih ada umat muslim yang tidak mengerjakannya.

Dosen: Adakah kalimat lain yang lebih spesifik yang dapat digunakan?

Mahasiswa: Ada pak, ada umat muslim yang tidak melaksanakan shalat lima waktu, padahal shalat lima waktu tersebut me rupakan kewajiban bagi umat muslim.

Dosen: Oke, bagus. Apakah ini berupa kesa lahan?

Mahasiswa: ya pak.
Dosen: Bagaimana dengan ada orang yang me lakukan judi, padahal judi itu perbuatan yang dilarang. Samakah jenis kesalahan yang diperbuat?

Mahasiswa: Tidak pak.

Dosen: Silahkan dianalisis berbagai persoalan yang telah Anda identifikasi terkait de ngan aturan dan aktivitas yang dila kukan manusia.

Dosen: Kalau begitu, coba ringkas berbagai ak tivitas yang dilakukan manusia terkait dengan menjalankan atau melanggar pe rintah yang telah ditetapkan.

Probing questions yang digunakan dosen dapat memfasilitasi mahasiswa menemukan dua tipe kesalahan yang dilakukan manusia dalam kehidupan. Beberapa mahasiswa merepresentasi kan menggunakan Tabel 2 x 2 seperti terlihat pada Gambar 4.

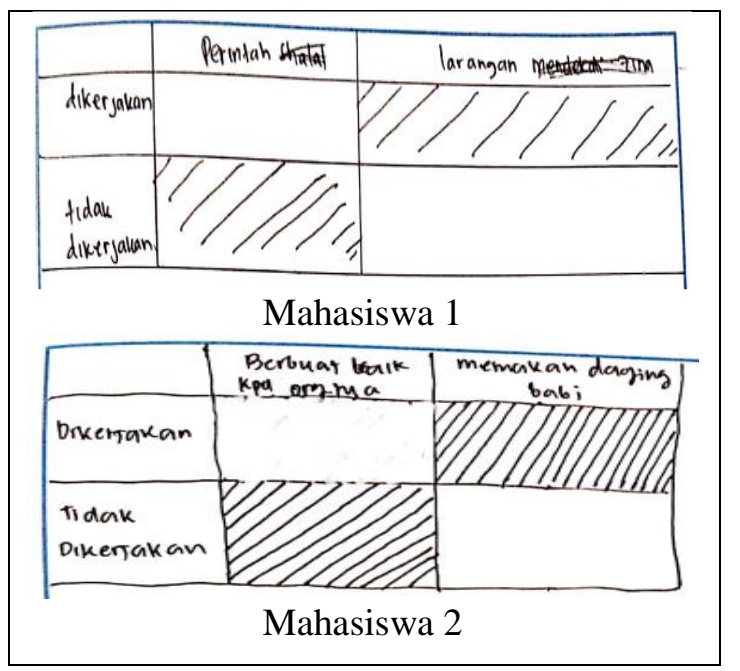

Gambar 4. Replika Hasil Pekerjaan Mahasiswa Terkait Aktivitas yang Dilakukan Manusia

Pada Gambar 4 terlihat bahwa Mahasiswa 1 telah memanfaatkan penalarannya dalam me ringkas aktivitas manusia dalam bentuk tabel $2 \mathrm{x}$ 2, namun mahasiswa 2 masih menyajikan hanya untuk salah satu kasus khusus. Kedua maha siswa telah mampu mengidentifikasi jenis kesa lahan yang dilakukan manusia dalam kehidupan (daerah diarsir), yaitu tidak mengerjakan perin tah dan mengerjakan larangan. Memanfaatkan model yang dibuat sendiri (Gambar 4), mahasis wa dapat mengonversi jenis kesalahan yang di lakukan manusia dalam kehidupan, menjadi kon sep dua tipe kesalahan dalam pengujian hipote sis, seperti terlihat pada Gambar 5. 


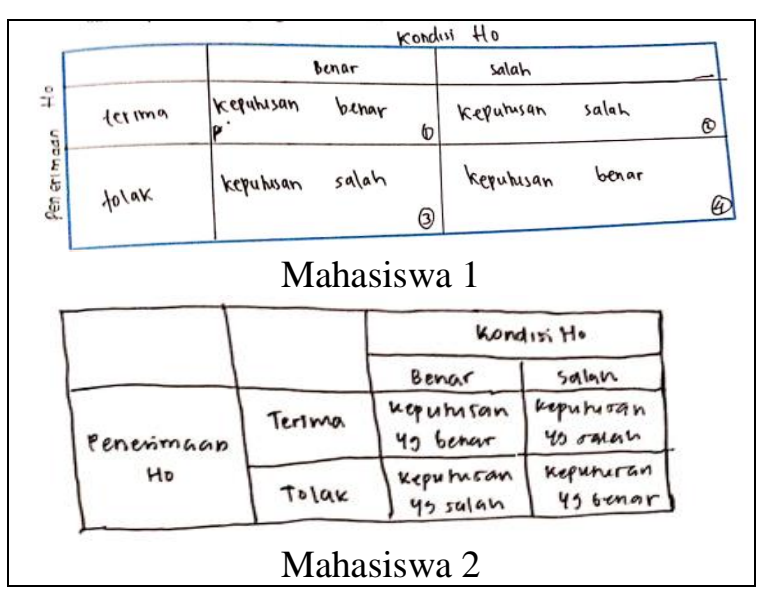

Gambar 5. Replika Hasil Pekerjaan Mahasiswa

Gambar 5 menunjukkan bahwa mahasis wa telah mampu mengidentifikasi jenis keputus an yang dapat diambil dalam pengujian hipote sis, yaitu keputusan yang benar (menerima $\mathrm{H}_{0}$ yang benar dan menolak $\mathrm{H}_{0}$ yang salah), serta keputusan yang salah (menolak $\mathrm{H}_{0}$ yang benar dan menerima $\mathrm{H}_{0}$ yang salah). Melalui diskusi kelompok, mahasiswa mampu menyatakan ber bagai keputusan dalam pengujian hipotesis da lam bentuk peluang, dan mendefinisikan dua je nis kesalahan dalam pengujian hipotesis, seperti yang terlihat pada Gambar 6.

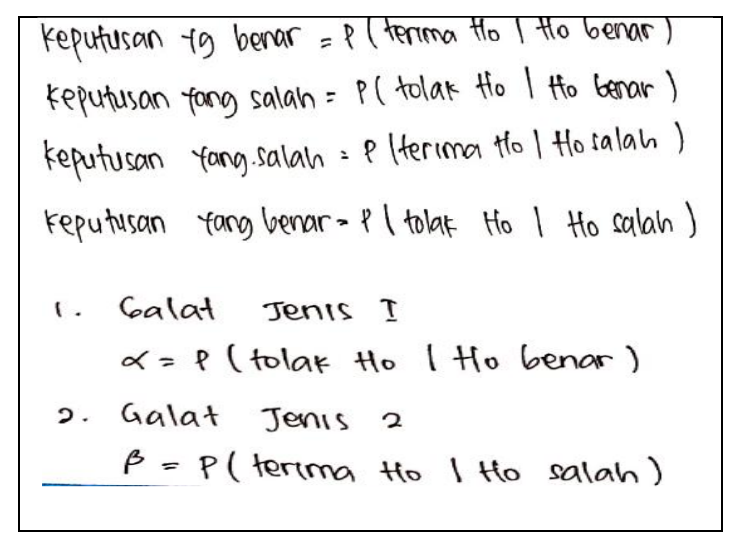

Gambar 6. Replika Hasil Pekerjaan Mahasiswa Terkait dengan Peluang Melakukan Kesalahan dalam Pengujian Hipotesis

Selanjutnya, konsep dua tipe kesalahan yang telah dikonstruksi mahasiswa dimanfaat kan untuk menentukan besarnya peluang me lakukan Galat Jenis I dan Galat Jenis II untuk kasus efektivitas vaksin Hepatitis B. Mahasiswa mampu merumuskan $\mathrm{H}_{0}$ dan $\mathrm{H}_{1}$ dari kasus terse but, serta mampu mendeteksi jenis distribusi yang sesuai dengan kasus yang dibahas. Meng gunakan konsep dua tipe kesalahan, mahasiswa mampu menentukan besarnya peluang melaku kan Galat Jenis I dan Galat Jenis II.
Lintasan pembelajaran yang telah diran cang melalui HLT dapat memfasilitasi mahasis wa melakukan proses matematisiasi horizontal dan matematisasi vertikal. Hal ini terlihat dari ke mampuan mahasiswa mengonstruksi berbagai je nis keputusan yang diperoleh dalam pengujian hipotesis melalui berbagai aktivitas manusia da lam kehidupan, yang pada akhirnya menemukan sendiri konsep dua tipe kesalahan dalam pengu jian hipotesis.

Selanjutnya, HLT yang telah dihasilkan dilakukan uji praktikalitas dengan menyebarkan angket praktikalitas kepada responden uji coba. Hasilnya seperti terlihat pada Tabel 7.

Tabel 7. Hasil Uji Kepraktisan Desian HLT

\begin{tabular}{llcl}
\hline No & Komponen & Nilai & Kategori \\
\hline 1. & Dapat digunakan & 3,28 & Sangat Praktis \\
2. & Mudah digunakan & 3,32 & Sangat Praktis \\
3. & Daya tarik & 3,32 & Sangat Praktis \\
& Rerata & 3,30 & Sangat Praktis \\
\hline
\end{tabular}

Hasil uji praktikalitas menunjukkan bahwa semua komponen yang diuji memiliki nilai prak tikalitas dengan kategori sangat praktis. Hal ini menunjukkan bahwa HLT yang dirancang layak menjadi LIT karena dapat dan mudah diguna kan, serta memiliki daya tarik dalam pengguna annya. Dengan demikian LIT dapat dimanfaat kan untuk memfasilitasi mahasiswa dalam mem pelajari topik pengujian hipotesis, khususnya mengonstruksi konsep dua tipe kesalahan dalam pengujian hipotesis. LIT yang dimaksud dapat dilihat pada Gambar 7.

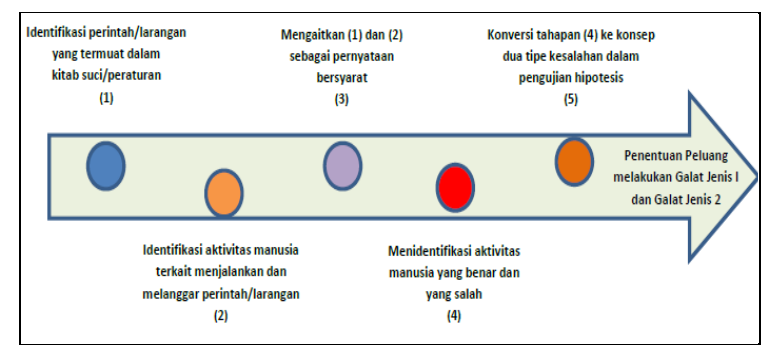

Gambar 7. Alur Belajar LIT Dua Tipe

Kesalahan dalam Pengujian Hipotesis

\section{KESIMPULAN}

Local Instructional Theory yang dihasil kan melalui proses siklik Hypothetical Learning Trajectory sangat praktis digunakan untuk mem fasilitasi mahasiswa melakukan proses matema tisasi horizontal dan matematisasi vertikal, se hingga mahasiswa mampu mengostruksi sendiri konsep dua tipe kesalahan dalam pengujian hipo tesis. Alur belajar yang dihasilkan adalah seba gai 
berikut (1) identifikasi perintah dan larangan yang terdapat dalam kitab suci/ peraturan; (2) identifikasi aktivitas manusia terkait menjalan kan dan melanggar perintah atau larangan; (3) menyajikan hasil (1) dan (2) dalam bentuk per nyataan bersyarat; (4) mengidentifikasi aktivitas manusia yang benar dan yang salah; (5) konversi tahapan (4) ke konsep dua tipe kesalahan dalam pengujian hipotesis; (6) penentuan peluang mela kukan Galat Jenis I dan Galat Jenis II.

\section{DAFTAR PUSTAKA}

Bohamonde, D.C, Joan, J.M.F. \& Aymemi. (2017). Mathematical modelling and the learning trajectory: tools to support the teaching of linear algebra. International Journal of Mathematical Education in Science and Tchnology, 48(3). doi: 10. 1080/0020739X.2016.1241436

Batanero, C. (2000). Controversies around the Role of Statistical Tests in Experimental Research. Mathematical Thinking and Learning, 2 (1-2): 75-98. doi: 10.1207/ S15327833MTL0202_4.

Bluman, A. G. (2012). Elementary Statistics: A step by step approach. $8^{\text {th }}$ eds. New York: McGraw Hill.

Brase, C. \& Brase, C. (2012). Understanding Basic Statistics. $7^{\text {th }}$ eds. Cengage Learn ing: Australia.

Castro, S. A. E., Vanhoof, S., Noortgate, W. V. den, \& Onghena, P. (2007). Students' misconceptions of statistical inference: A review of the empirical evidence from research on statistics education. $E d u$ cational Research Review, 2(2), 98 113. doi: 10.1016/j.edurev.2007.04.001.

Confrey, J., Gianopulos, G., McGowan, W., Shah, M., \& Belcher, M. (2017). Sca ffolding learner-centered curricular cohe rence using learning maps and diag nostic assessments designed around mathematics learning trajectories. ZDM Mathematics Education, 49(5), 717-734. doi:10.1007/ s1 1858-017-0869-1

Daro, P., Mosher, Frederic, A., \& Corcoran, T. B. (2011). Learning Trajectories In Mathematics: A Foundation for Standar, Curriculum, Assesment, and Instruction. From 10.12698/cpre.2011.rr68

Fauzan, A., Yerizon, Tasman, F., Yolanda, R. N. (2020). Pengembangan Local Instruc tional Theory Pada Topik Pembagian dengan Pendekatan Matematika Realis tik. Jurnal Eksakta Pendidikan, 4 (1): 19. doi: 10.24036/jep/vol4-iss 1/417

Gravemeijer, K. (2004). Local instruction theo ries as a means of support for teachers in reform mathematics education. Mathe matical Thinking and Learning, 6(2), 105-128. doi: 10.1207/s1532833mtl06 02_3

Gravemeijer, K., \& Cobb, P. (2013). Design research from the learning design perspective. In Plomp T., \& N. Nieveen (Eds.), Educational Design research. Part A: An introduction (pp. 72-113). Enschede: Netherlands: SLO.

Gravemeijer, K. (2014). Design research on local instruction theories in mathematics education. Development of Mathematics teaching: Design, Scale, Effects. Pro ceedings of MADIF 9 (The Ninth Swe dish Mathematics Education Research Seminar Umeå).

Jacob, B. L. (2013). The Development of Introductory Statistics Students' Infor mal Inferential Reasoning and Its Rela tionship to Formal Inferential Reason ing. Teaching and Leadership - Disserta tions. 245.

Jhonson, A. C. \& Drougas, A. M. (2004). Illustrating type i dan type ii errors via spreadsheet simulation in the business statistics course. Decission Sciences Jor nal of Innovative Education, 2 (1): 89-95. doi: 10.1111/j.0011.2004.00024.X

Larson, C.A., Wawro, M. \& Zandieh, M. (2017). A hypothetical learning trajec tory for conceptualizing matrices as li near transformations. International Jour nal of Mathematical Education in Scien ce and Technology. doi: 10.1080/ 0020739X. 2016.1276225.

Lemsan, S. C., \& House, L. (2012). Improving Mr. Miyagi's Coaching Style: Teaching Data Analytics with Interactive Data Visualizations, CHANCE, 25(2): 4-12. doi:10.1080/09332480.2012.685362.

Muliyardi. (2006). Pengembangan Model Pem belajaran Matematika dengan Menggu nakan Komik di Kelas I Sekolah Dasar. Disertasi. Surabaya: Pascasarjana Uni versitas Surabaya.

Peraturan Presiden Republik Indonesia Nomor 8 Tahun 2012, tentang Kerangka Kualifi kasi Nasional Indonesia. Jakarta: Lem 
baran Negara Republik Indonesia Tahun 2012 Nomor 24.

Simon, M. (1995). Reconstructing mathematics pedagogy from a constructivist perspec tive. Journal for Research in Mathe matics Education, 26(2), 114-145. doi: $10.2307 / 749205$.

Syafriandi. (2020). Pengembangan local in structional theory berbasis realistic ma thematics education untuk topik pengu jian hipo tesis. Disertasi. Pascasarjana Universitas Negeri Padang.

Syafriandi, S. Fauzan, A., Lufri, L., Armiati, A. (2020). Designing hypothetical learn ing trajectory for learning the impor tance of hypothesis testing. Journal of Physics:
Conference Series 1554 (2020) 012045. IOP Publishing. doi:10.1088/ 17426596/1554/1/012045.

Sztajn, P., Confrey, J., Wilson, P. H., \& Edging ton, C. (2012). Learning trajectory based instruction toward a theory of teaching. Educational Researcher, 41(5), 147-156. doi: 10.3102/0013189x12442801.

Triola, Mario F. (2012). Elementary Statistics Technology, $11^{\text {th }}$ eds. New York: Addison -Wesley.

Van den Heuvel-Panhuizen, M., \& Drijvers, P. (2020). Realistic mathematics education. S. Lerman (ed.), Encyclopedia of Mathe matics Education. Doi: 10.1007/978-94007-4978-8. 